\title{
44. LIPID GEOCHEMISTRY OF CRETACEOUS BLACK SHALES FROM THE BAY OF BISCAY, SITE 402, AND OF EOCENE MUDSTONE FROM THE ROCKALL PLATEAU, SITE 404 ${ }^{1}$
}

\author{
Bernd R.T. Simoneit, Institute of Geophysics and Planetary Physics, University of California, Los Angeles, California
}

\begin{abstract}
The lipids extracted from Cretaceous mudstones from the northern North Atlantic Ocean (Hole 402A). The distribution patterns of the $n$-alkanes, $n$-fatty acids, and $n$-alkan-2-ones indicated a predominant allochthonous terrigenous origin, with a minor autochthonous marine component. Molecular markers of both marine and terrestrial origins were identified. The sedimentation took place under oxic conditions with rapid influx of terrigenous detritus.

The lipids of an Eocene sample from Site 404 were of a predominantly marine origin with only traces of molecular markers from terrestrial sources. This sediment was deposited in oxic deep waters.

The $17 \beta(\mathrm{H}), 21 \beta(\mathrm{H})$-hopane series was predominant in all these samples, indicating that these sediments are very immature and have had a mild geothermal history.
\end{abstract}

\section{INTRODUCTION}

The Cretaceous black shales that have been encountered in the Atlantic Ocean had various sedimentary origins. Some were formed in anoxic basins with high sedimentation rates and large components of terrigenous organic matter; other black shales were formed at the continental margins by rapid turbidite influx of oxidized organic matter, in shallow epi-continental and marginal seas with high autochthonous productivity, or under various other paleoenvironmental conditions (e.g., Schlanger and Jenkyns, 1976; Simoneit, in press). Therefore, it was of interest to determine if, in the case of the Bay of Biscay sediments, the analyses of the lipids would allow a distinction to be made between the influx of allochthonous and the production of autochthonous material. Also, a comparison of these results with similar data for samples from other areas of the Atlantic Ocean will contribute to the overall assessment of the paleoenvironment of the proto-Atlantic.

The samples examined here were derived from Hole $402 \mathrm{~A}\left(47^{\circ} 52.48^{\prime} \mathrm{N}, 08^{\circ} 50.44^{\prime} \mathrm{W} ; 2339.5 \mathrm{~m}\right.$ water depth), located in a canyon on the mid-continental slope of the Bay of Biscay (Montadert et al., 1976). The Aptian sequence was deposited in less than 200 meters depth in an oxic environment with a high influx rate of terrigenous detritus (Montadert et al., 1976).

An Eocene mudstone from Site $404\left(56^{\circ} 03.13^{\prime} \mathrm{N}\right.$, $23^{\circ} 14.95^{\prime} \mathrm{W} ; 2306 \mathrm{~m}$ water depth) also was analyzed for general comparison. This site is located on the rifted southwest margin of the Rockall Plateau and probably represented a near littoral paleoenvironment (Montadert et al., 1976).

\footnotetext{
'Contribution 1785 from the Institute of Geophysics and Planetary
} Physics, University of California, Los Angeles, California.

\section{EXPERIMENTAL}

The core samples were freeze-dried and then extracted with toluene and methanol (3:7) in a Soxhlet apparatus (300 cycles of solvent change). The extracts for each sample were concentrated on a rotary evaporator, treated with $\mathrm{BF}_{3}$ in methanol to esterify free acids, and then subjected to silica-gel thin-layer chromatography (TLC) using methylene chloride as eluent. After development with iodine vapor, the bands corresponding to hydrocarbons and esters with ketones were scraped off the TLC plate and eluted with methylene chloride. These fractions were subjected to gas chromatographic (GC) and GC/MS analyses.

The GC analyses were conducted on a Varian Aerograph Model 1520 gas chromatograph using a $30 \mathrm{~m} \times 0.25 \mathrm{~mm}$ glass capillary column wall-coated with OV-101, programmed from $40-260^{\circ} \mathrm{C}$ at $6^{\circ} \mathrm{C} / \mathrm{min}$, then held isothermal for 80 minutes, and using $\mathrm{He}$ carrier gas at a flow rate of $2 \mathrm{ml} / \mathrm{min}$ (30 $\mathrm{cm} / \mathrm{s}$ linear velocity).

The GC/MS analyses were conducted on a Finnigan Model 4000 quadrupole mass spectrometer interfaced directly with a Finnigan Model 9610 gas chromatograph equipped with a $30 \mathrm{~m} \times 0.75 \mathrm{~mm}$ glass capillary column (J\&W, Inc.) which was wall-coated with OV-101. The GC conditions for the GC/MS analyses were as those for the analytical GC system. The mass spectrometric data were acquired and processed using a Finnigan-Incos Model 2300 data system.

\section{RESULTS AND DISCUSSION}

The sample descriptions, carbon and lipid analyses, and other results are given in Table 1. The Cretaceous samples that were examined consist of gray mudstone with an organic carbon content of about 2 per cent, and the Eocene sample consists of green mudstone with about 0.3 per cent organic carbon. The lipid yields for all samples were low. 
TABLE 1

Sample Descriptions, Carbon Analyses, and Lipid Yields for the Core Samples Examined From Leg 48

\begin{tabular}{|c|c|c|c|c|c|c|c|c|c|c|c|c|c|c|c|c|c|c|}
\hline \multirow[b]{2}{*}{$\begin{array}{c}\text { Sample } \\
\text { (Interval in cm) }\end{array}$} & \multirow{2}{*}{$\begin{array}{c}\text { Depth } \\
\text { Below } \\
\text { Sea Bed } \\
\text { (m) }\end{array}$} & \multirow[b]{2}{*}{ Lithology } & \multirow[b]{2}{*}{$\begin{array}{c}\text { Geologic } \\
\text { Age }\end{array}$} & \multicolumn{3}{|c|}{ Carbon $(\%)^{\mathrm{a}}$} & \multirow[b]{2}{*}{$\underset{(\mu \mathrm{g} / \mathrm{g})}{\mathrm{HC}}$} & \multicolumn{3}{|c|}{$n$-alkanes } & \multicolumn{3}{|c|}{$n$-fatty acids } & \multicolumn{3}{|c|}{$n$-methylketones } & \multirow[b]{2}{*}{$\mathrm{Pr} / \mathrm{Ph}^{\mathrm{d}}$} & \multirow[b]{2}{*}{ Perylene } \\
\hline & & & & Total & Org. & $\mathrm{CaCO}_{3}$ & & $(\mu \mathrm{g} / \mathrm{g})$ & $\mathrm{CPI}^{\mathrm{b}}$ & $\max .^{c}$ & $\begin{array}{r}\text { Total } \\
(\mu \mathrm{g} / \mathrm{g})\end{array}$ & $\mathrm{CPI}^{\mathrm{b}}$ & $\max .^{c}$ & $(\mu g / g)$ & $\mathrm{CPI}^{\mathrm{b}}$ & $\max .^{c}$ & & \\
\hline $402 \mathrm{~A}-21-1,40-44$ & 327.4 & $\begin{array}{l}\text { Gray mud- } \\
\text { stone }\end{array}$ & $\begin{array}{l}\text { Cretaceous } \\
\text { (Aptian) }\end{array}$ & 4.64 & 1.73 & 24 & 17 & 0.30 & 2.7 & $\begin{array}{l}19,23, \\
27,33\end{array}$ & 28.0 & 3.2 & $16, \underline{28}$ & 1.2 & 1.8 & $\underline{19,25}$ & 1.40 & 0 \\
\hline $402 \mathrm{~A}-30-1,20-27$ & 412.7 & $\begin{array}{l}\text { Gray mud- } \\
\text { stone }\end{array}$ & $\begin{array}{l}\text { Cretaceous } \\
\text { (Aptian) }\end{array}$ & 5.54 & 1.95 & 30 & 13 & 0.50 & 1.7 & $\frac{19,23}{27}$, & 1.4 & 3.6 & $16, \underline{28}$ & 0.22 & 2.3 & $\frac{13,19}{29}$, & 2.00 & 0 \\
\hline $402 \mathrm{~A}-35-4,13-25$ & 464.7 & $\begin{array}{l}\text { Gray mud- } \\
\text { stone }\end{array}$ & $\begin{array}{l}\text { Cretaceous } \\
\text { (Aptian) }\end{array}$ & 2.48 & 0.11 & 20 & a.d. ${ }^{\mathrm{e}}$ & n.d. & - & - & n.d. & - & - & n.d. & - & - & - & - \\
\hline $404-22-6,25-50$ & 349.4 & $\begin{array}{l}\text { Green-gray } \\
\text { mudstone }\end{array}$ & Eocene & 0.96 & 0.25 & 6 & 15 & 0.06 & 1.1 & $17, \underline{23}$ & 0.8 & 4.9 & $\frac{16,22}{28}$ & 0.04 & 1.6 & $\underline{15}, 27$ & 1.45 & 0 \\
\hline
\end{tabular}

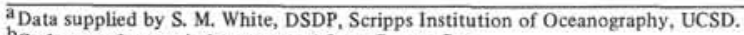

${ }^{b}$ Carbon preference index, summed from $C_{10}$ to $C_{35}$.

${ }^{\mathrm{c}}$ The predominant maximum is underscored

Pristane-to-phytane ratio.

\section{Samples 402A-21-1, 40-44 cm and 402A-30-1, 20-27 cm}

The distribution diagrams for the $n$-alkanes, $n$-fatty acids, and $n$-alkan-2-ones are shown in Figure 1 . The $n$-alkanes of both samples exhibit distributions with major maxima at $n-\mathrm{C}_{23}, n-\mathrm{C}_{27}$, and $n-\mathrm{C}_{33}$; minor maxima at $n-\mathrm{C}_{19}$; and a strong odd-to-even carbon number predominance $>n-\mathrm{C}_{23}$. The homologs $>n-C_{23}$ are attributable to an origin from higher plant wax (Simoneit, 1975; 1977a; 1978b), and the homologs $>n-\mathrm{C}_{22}$ are probably derived from autochthonous marine sources (Simoneit, 1975; in press). The pristane-to-phytane ratio of both samples is greater than one and both perylene and sulfur are not present in significant amounts, indicating that this sediment accumulated under oxic paleoenvironmental conditions (Didyk et al., 1978). This is corroborated by the preliminary shipboard analysis (Montadert et al., 1976). The $n$-fatty acids of both samples exhibit bimodal distributions with major maxima at $n-\mathrm{C}_{28}$, minor maxima at $n-\mathrm{C}_{16}$, and a strong even-to-odd carbon number predominance. The homologs $>n-\mathrm{C}_{22}$, when considered in conjunction with the $n$-alkane distributions, are further markers of allochthonous higher plant lipids (Simoneit, 1975; in press). The homologs $<n-C_{20}$ appear to be of autochthonous marine origin (Simoneit, 1975). The $n$-alkan-2-ones also exhibit a bimodal distribution, with maxima at $\mathrm{C}_{19}$ and $\mathrm{C}_{27}$ and a strong odd-to-even carbon number predominance. These methylketones are probably derived from $n$-fatty acids by microbial $\beta$-oxidation or by microbial oxidation of $n$-alkanes (Arpino, 1973). The ketone distributions reflect a partial terrigenous origin (homologs $>\mathrm{C}_{20}$ ), as was the case for the samples from the Black Sea (Simoneit, 1978). The isoprenoidal ketones $(6,10,14$-trimethylpentadecan-2-one and 6,10-dimethylundecan-2-one, cf., Figure $1 \mathrm{~g}, \mathrm{~h}$ ) are the predominant ketones and reflect oxidative products of phytol (Simoneit, 1973).

The minor molecular markers are comprised of hydrocarbons, acids and ketones. Steranes and sterenes are present only in traces in these two samples. Triterpanes are found as significant components and their relative distributions are shown in Figure $2 \mathrm{a}, \mathrm{b}$. The predominant analogs are the $17 \beta(\mathrm{H}), 21 \beta(\mathrm{H})$-hopanes, $\mathrm{C}_{n} \mathrm{H}_{2 n-8}$, ranging over $n=27,29$ and 30 (Structure I) and 31-35, with only one diastereomer at $\mathrm{C}-22$ (Structure II). $17 \beta(\mathrm{H})$, $21 \beta(\mathrm{H})$-homohopane (II, $\mathrm{R}=\mathrm{CH}_{3}$ ) is the predominant triterpane for both samples. Lesser amounts of $17 \alpha(\mathrm{H}), 21 \beta(\mathrm{H})$-hopanes and various moretanes are also present. Both samples contain some of the aromatized triterpenoids which were characterized in Messel shale and confirmed by synthesis (Greiner et al., 1976) and which were found previously in Samples 40-364-24-1, 0-10 cm, and 41-367-19-4, 10-15 cm (Simoneit, 1977c, 1979). The following compounds were identified by their characteristic mass spectra (Spyckerelle, 1975): 8,14,18-trisnormethyladianta-8,11,13,15,17-pentaene [( $3^{\prime}$-ethylcyclopenteno-7, 8) 1, 1, 15-trimethyloctahydro $(1,2,3,4,5,6,7,8)$ chrysene - Structure III], (3'-ethylcyclopenteno-7,8) 1,1-dimethyltetrahydro $(1,2,3,4)$ chrysene (Structure IV), a higher homolog, $\mathrm{C}_{26} \mathrm{H}_{30}$ (IV, with an additional $\mathrm{CH}_{3}$ in ring $\mathrm{A}$ or $\left.\mathrm{B}\right)$, and (3'-ethylcyclopenteno-7,8) 1-methylchrysene (Structure V). These compounds probably represent diagenetic products from hopanes of marine origin.

Other hydrocarbons that have been identified consist of diterpenoids, sesquiterpenoids, and isoprenoids. The predominant diterpenoids are dehydroabietane (VI); dehydroabietin (VII), simonellite (VIII), and retene (IX), with lesser amounts of tetrahydro( $1,2,3,4)$ retene [1-methyl-7-(2'-propyl) tetrahydro(1,2,3,4)-phenanthrene] (X), 17-nordehydroabietane (XI), and various methyl- and dimethylphenanthrenes. (The relative concentrations of these compounds and of the sesquiterpenoids are indicated in Figure 2a,b.) These diterpenoids are molecular markers derived from resinous vascular plants (Simoneit, 1977b). The sesquiterpenoids consist of tetrahydro $(1,2,3,4) \delta$ cadalene (XII) and cadalene (XIII), which may be derived from marine and/or terrigenous sources. Pristane and phytane are present in minor amounts $(\mathrm{Pr} / \mathrm{Ph}>1)$ and farnesane is not detectable.

The carboxylic acid markers of both samples consist predominantly of triterpenoid and diterpenoid acids. The extended $17 \beta(\mathrm{H}), 21 \beta(\mathrm{H})$-hopanoic acids, $\mathrm{C}_{n} \mathrm{H}_{2 n-10} \mathrm{O}_{2}$ (XIV), range from $n=31$ to 33 and their concentrations are summarized in Table 2. These compounds represent oxidation residues from bacteriohopanepolyols (Rohmer, $1975)$, and their predominantly $17 \beta(\mathrm{H})$ stereochemistry indicates geologic immaturity (Dastillung and Albrecht, 1976). Dehydroabietic acid (XV) is present in both samples and is derived from terrigenous resinous plants (Simoneit, 1977b). 

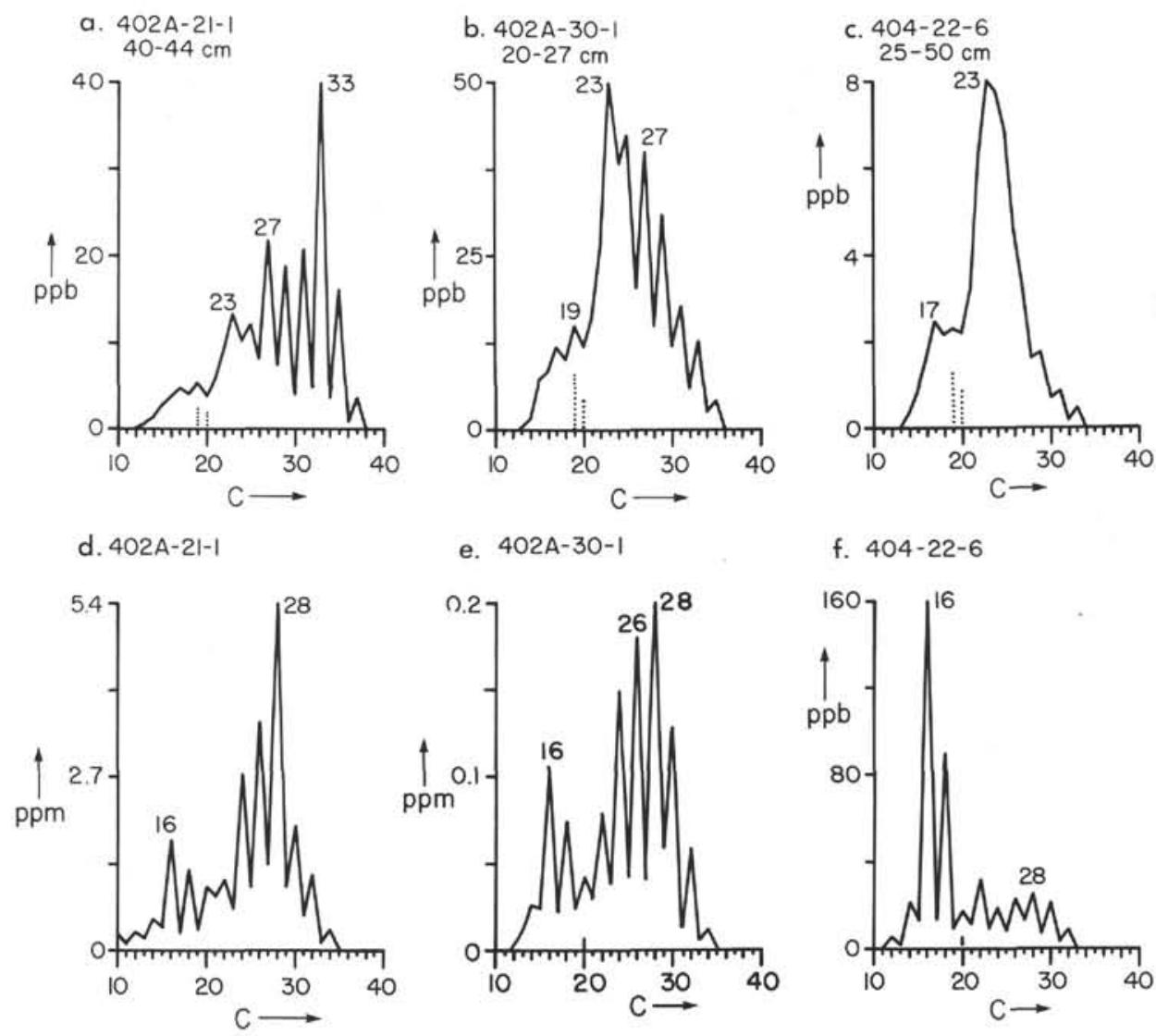

e. $402 A-30-1$

\section{f. $404-22-6$}
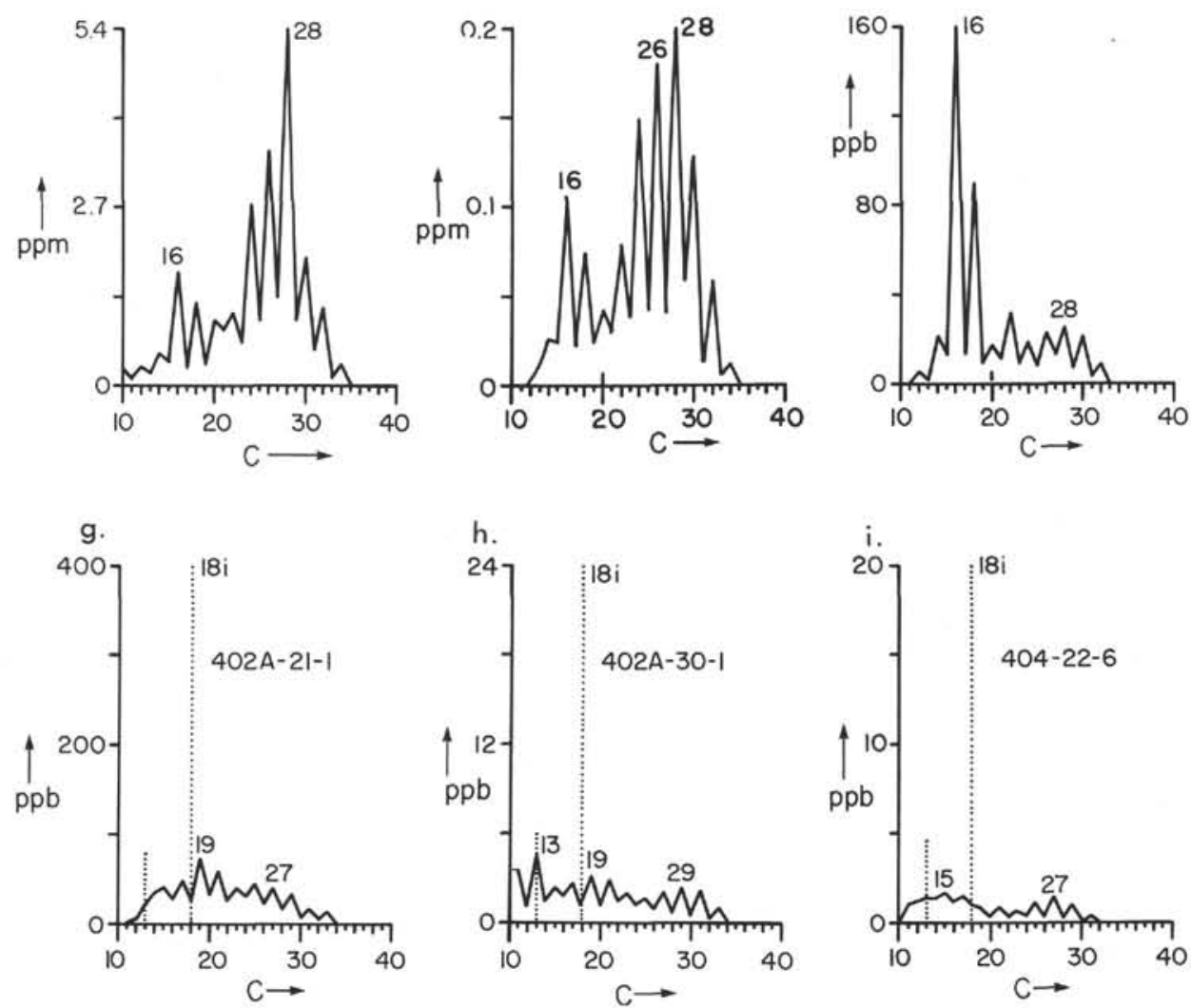

Figure 1. Concentrations of n-alkanes $(a-c)$, n-fatty acids $(d-f)$ and n-alkan-2-ones ( $g$-i). Isoprenoids $(\cdots \cdots)$ and dehydroabietic acid (---- ) are also indicated.

The ketone markers of both samples consist mainly of triterpenoids. The major analogs are $17 \beta(\mathrm{H})$ trisnorhopan-21-one (XVI) and probably $17 \beta(\mathrm{H})$,$21 \beta(\mathrm{H})$-norhopan-22-one (XVII) (Simoneit, 1978), with lesser amounts of the $17 \alpha(\mathrm{H})$ structures and several isomers of a $\mathrm{C}_{31} \mathrm{H}_{52} \mathrm{O}$ ketone. The mass spectra of the two predominant isomers of the $\mathrm{C}_{31} \mathrm{H}_{52} \mathrm{O}$ ketone are shown in Figure 3. The fragmentation scheme, shown in Figure 4, best fits significant ions at $\mathrm{m} / \mathrm{e} 147,191,219,355,368$, 422,425 and the molecular ion, 440 . Thus, the proposed structure for these ketones is homohopan-29-one (XVIII), and the stereochemistry at C-17 and C-21 needs to be confirmed with authentic standards. The mass spectrometric fragmentation pattern does not fit for a nonhopane skeleton or for homohopan-31-one. These homohopan-29-ones have not been identified before in any sample and may represent diagenetic products of bacteriohopanepolyols. The norhopanones have been characterized in sediments from the Black Sea (Simoneit, 1978) and may represent degradation products of the bacteriohopanepolyols.

\section{Sample 404-22-6, $25-50 \mathrm{~cm}$}

The $n$-alkanes of this sample exhibit an essentially unimodal distribution (Figure 1c) with a maximum at $n-\mathrm{C}_{23}$ and no carbon number predominance. This distribution is typical of a microbially degraded, algal-lipid residue (e.g., 

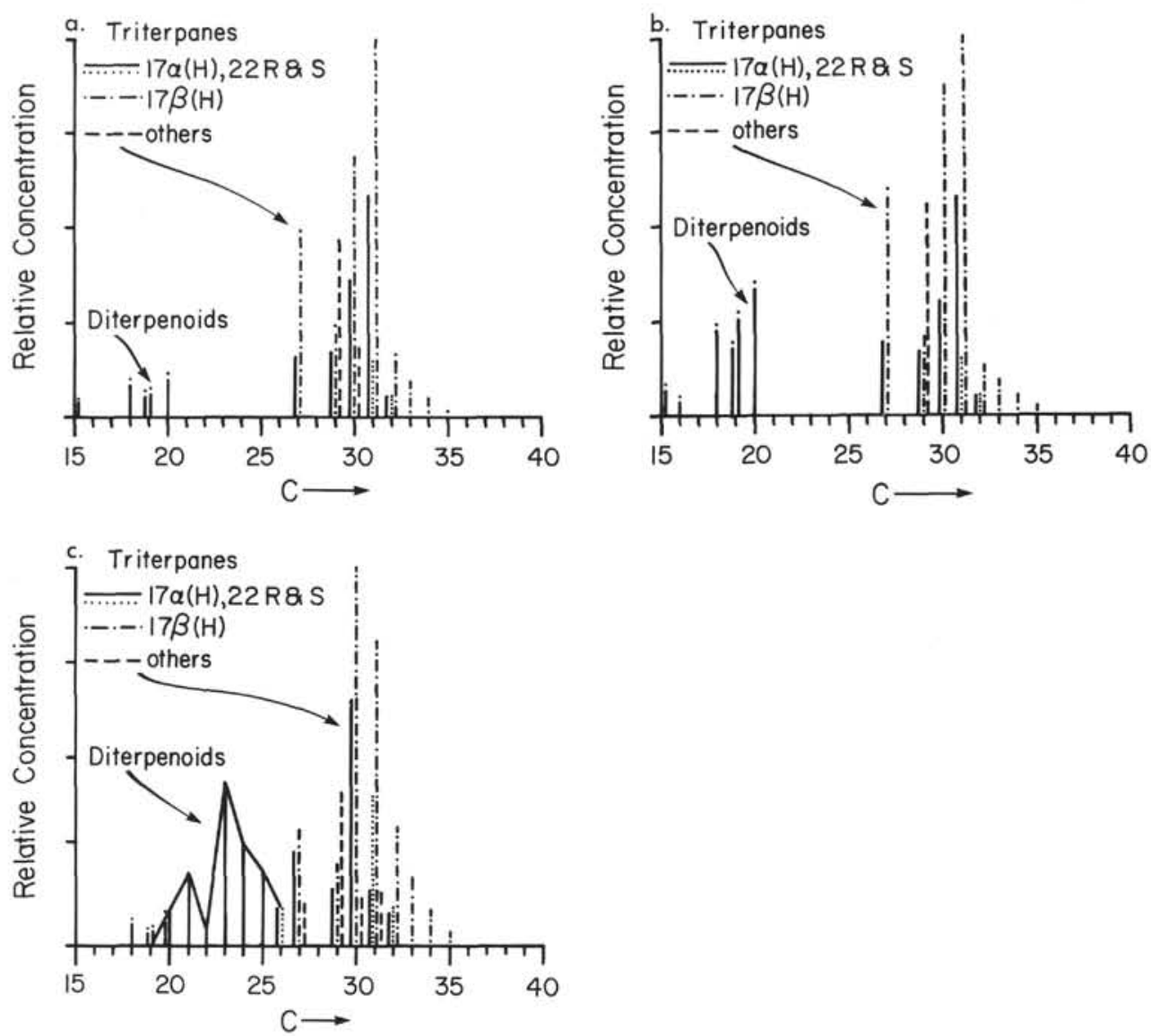

Figure 2. Relative concentrations of triterpanes and diterpenoids: (a) Sample 402A-21-1, 40-44 cm; (b) Sample 402A-30-1, 20-27 cm; (c) Sample 404-22-6, 25-50 cm.

TABLE 2

Concentrations of Triterpenoidal Acids

\begin{tabular}{|c|c|c|c|c|}
\hline \multirow[b]{2}{*}{ Compor } & \multirow{2}{*}{$\begin{array}{l}\text { Kovats Index } \\
\text { (methyl esters } \\
\text { on OV-101) } \\
\end{array}$} & \multicolumn{3}{|c|}{ Sample (Interval in cm) } \\
\hline & & $\begin{array}{l}402 \mathrm{~A}-21-1 \\
40-44\end{array}$ & $\begin{array}{l}402 \mathrm{~A}-30-1, \\
20-27\end{array}$ & $\begin{array}{l}404-22-6, \\
25-50\end{array}$ \\
\hline $\begin{array}{l}17 \beta(\mathrm{H}), 21 \beta(\mathrm{H}) \text {-Homohopanoic } \\
\text { acid }\end{array}$ & 3304 & $2 \mu \mathrm{g} / \mathrm{g}^{\mathrm{a}}$ & $48 \mathrm{ng} / \mathrm{g}^{\mathrm{a}}$ & $4 \mathrm{ng} / \mathrm{g}^{\mathrm{a}}$ \\
\hline $\begin{array}{l}17 \beta(\mathrm{H}), 21 \beta(\mathrm{H}) \text {-Bishomohopanoic } \\
\text { acid }\end{array}$ & 3428 & $10 \mu \mathrm{g} / \mathrm{g}$ & $200 \mathrm{ng} / \mathrm{g}$ & $20 \mathrm{ng} / \mathrm{g}$ \\
\hline $\begin{array}{l}\text { 17 } \beta(\mathrm{H}), 21 \beta(\mathrm{H}) \text {-Trishomohopanoic } \\
\text { acid }\end{array}$ & - & $1 \mu \mathrm{g} / \mathrm{g}$ & $20 \mathrm{ng} / \mathrm{g}$ & $3 \mathrm{ng} / \mathrm{g}$ \\
\hline $\begin{array}{l}17 \alpha(\mathrm{H}), 21 \beta(\mathrm{H}) \text {-Bishomohopanoic } \\
\text { acid }(\mathrm{R}, \mathrm{S})\end{array}$ & $3280 / 3317$ & $1 / 1 \mu \mathrm{g} / \mathrm{g}$ & $10 / 8 \mathrm{ng} / \mathrm{g}$ & n.d. ${ }^{b}$ \\
\hline
\end{tabular}

${ }_{b}^{a}$ Concentration based on dry weight of sediment.

$b_{\text {n.d. }}=$ not detected.

Hatcher et al., 1977). Only traces of $n$-alkanes $\left(>n-\mathrm{C}_{27}\right.$, odd $\mathrm{C}$ predominance) derived from higher plant wax are present. The isoprenoids pristane and phytane are present as minor components and farnesane is not detectable. Their ratio $(\mathrm{Pr} / \mathrm{Ph})$ is 1.45 , and the sulfur content is low, which indicates oxic paleoenvironmental conditions of sedimentation (Didyk et al., 1978). The $n$-fatty acids exhibit a bimodal distribution, with a major maximum at $n-\mathrm{C}_{16}$, a minor one at $n-\mathrm{C}_{28}$ and a strong even-to-odd carbon number predominance (Figure 1f). The homologs $<n-\mathrm{C}_{20}$ are of an autochthonous marine origin and the homologs $>n-\mathrm{C}_{22}$ represent a minor influx of allochthonous terrigenous matter derived from higher plants (Simoneit, 1975, in press). The $n$-alkan-2-ones also exhibit a bimodal distribution with maxima at $\mathrm{C}_{15}$ and $\mathrm{C}_{27}$ and an odd-to-even carbon number predominance (Figure 1i). The isoprenoidal ketones are dominant. The ketones reflect oxidative degradation products from alkanes or fatty acids (Arpino, 1973) and phytol, respectively (Simoneit, 1973).

The minor molecular markers are comprised of hydrocarbons, acids, and ketones. Steranes are present as minor components in a complex mixture of various isomers. The relative distribution of the triterpanes and diterpenoids is shown in Figure $2 \mathrm{c}$. The predominant analogs are the $17 \beta(\mathrm{H}), 21 \beta(\mathrm{H})$-hopanes, $\mathrm{C}_{n} \mathrm{H}_{2 n-8}$, with $n=27,29,30$ (I) and 31-35 (one diastereomer only at C-22, II). $17 \beta(\mathrm{H}), 21 \beta(\mathrm{H})$-homohopane (II, $\mathrm{R}=\mathrm{CH}_{3}$ ) is the major analog present, and $17 \alpha(\mathrm{H}), 21 \beta(\mathrm{H})$-hopanes and moretanes are lesser constituents. Aromatized triterpenoids are found as minor components, and ( $3^{\prime}$-ethylcyclopenteno-7,8) 1,1-dimethyltetrahydro(1,2,3,4)-chrysene (Structure IV) and ( 3 '-ethylcyclopenteno-7,8)1-methylchrysene (Structure V) are confirmed. These triterpenoids probably represent diagenetic products from hopanes of autochthonous origin. Diterpenoid and traces of sesquiterpenoid hydrocarbons are present. The predominant diterpenoids consist of diterpanes, $\mathrm{C}_{n} \mathrm{H}_{2 n-4}$, ranging from $n=20$ to 26 (XIX) (Figure 2c), where the $\mathrm{C}_{26} \mathrm{H}_{48}$ homolog is resolved into the $\mathrm{R}$ and $\mathrm{S}$ diastereomers. These diterpanes have been identified in petroleums and some Recent algal sediments (Simoneit and 

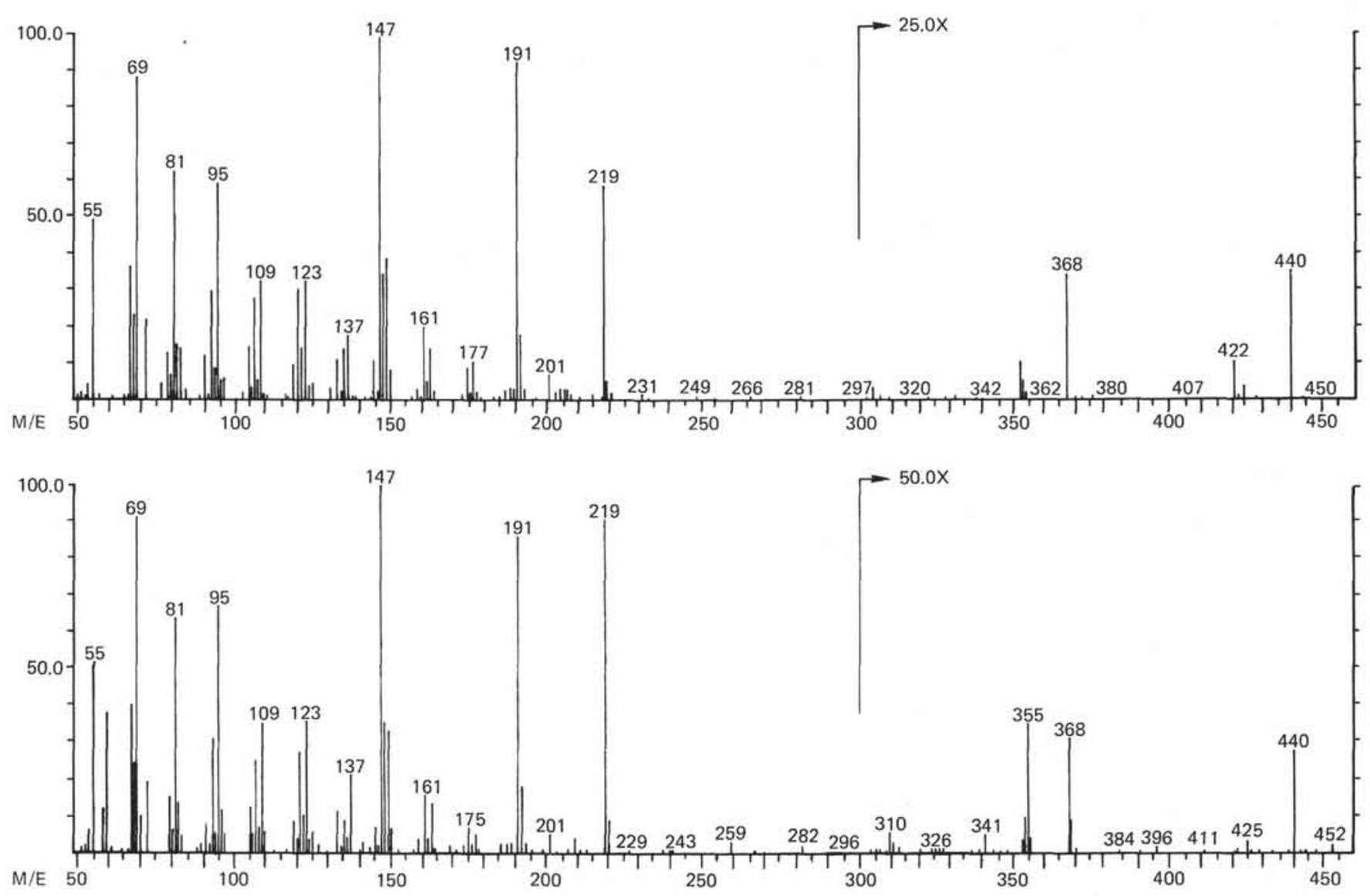

Figure 3. Mass spectra (GC/MS Finnigan Model 4000 quadrupole) of two isomers of homohopan-29-ones from Sample $402 A-21-1,40-44 \mathrm{~cm}$.

Kaplan, in press) and may be molecular markers with a marine origin. Minor amounts of the allochthonous terrigenous diterpenoids are also present: they are dehydroabietane (VI), dehydroabietin (VII), retene (IX), and traces of simonellite (VIII) and the sesquiterpenoids cadalene (XIII) and tetrahydrocadalene (XII). A trace of dehydroabietic acid (XV) is present in the acid fraction. The extended $17 \beta(\mathrm{H}), 21 \beta(\mathrm{H})$-hopanoic acids, $\mathrm{C}_{n} \mathrm{H}_{2 n-10} \mathrm{O}_{2}$ (XIV), range from $n=31$ to 33 and their concentrations are given in Table 2 . These acids represent oxidation products from autochthonous bacteriohopanepolyols, and their $17 \beta(\mathrm{H})$ stereochemistry indicates geologic immaturity (Dastillung and Albrecht, 1976). Significant amounts of $17 \beta(\mathrm{H})$-trisnorhopan-21-one (XVI) and probably $17 \beta(\mathrm{H})$,$21 \beta(\mathrm{H})$-norhopan-22-one (XVII) and traces of two isomers of homohopan-29-one are present. These ketones may reflect the degradation products of autochthonous bacteriohopanepolyols.

\section{CONCLUSIONS}

The lipids of the two Cretaceous mudstones are of a predominantly terrigenous-allochthonous origin. This is indicated by the distributions of the $n$-alkanes $\left(>n-\mathrm{C}_{23}\right)$, $n$-fatty acids $\left(>n-\mathrm{C}_{22}\right)$, and $n$-alkan-2-ones $\left(>\mathrm{C}_{21}\right)$ and is supported by the presence of molecular markers of terrestrial origin, which are comprised of diterpenoids and sesquiterpenoids. The paleoenvironmental conditions of sedimentation were controlled by rapid influx of terrigenous detritus, superimposed on autochthonous productivity in oxic waters. This observation is based on the pristaneto-phytane ratio greater than about one, the absence of sulfur and perylene, and the presence of oxidation products from autochthonous precursors such as bacteriohopanepolyls.

The lipids of the Eocene mudstone are of a predominantly autochthonous marine origin. This is indicated mainly by the distributions of the $n$-alkanes (maximum at $n-\mathrm{C}_{23}$ ) and $n$-fatty acids (maximum at $n-\mathrm{C}_{16}$ ) and the presence of the only minor amounts of molecular markers of a terrigenous origin. These data, the pristane-to-phytane ratio of 1.45 , the absence of perylene and sulfur, and the presence of autochthonous triterpenoidal oxidation products indicate that this Eocene mudstone is from an oxic, deep water paleoenvironment, with little terrestrial influx.

These inferences are in agreement with the preliminary description of the sedimentary record that has been presented (Montadert et al., 1976). The predominance of the $17 \beta(\mathrm{H}), 21 \beta(\mathrm{H})$-hopane series in all three samples indicates the geologic immaturity of the sediments.

\section{ACKNOWLEDGMENTS}

I thank the National Science Foundation for making the core samples available, Monica Mazurek for technical assistance, and E. Ruth for assistance with GC/MS data acquisition. Partial 


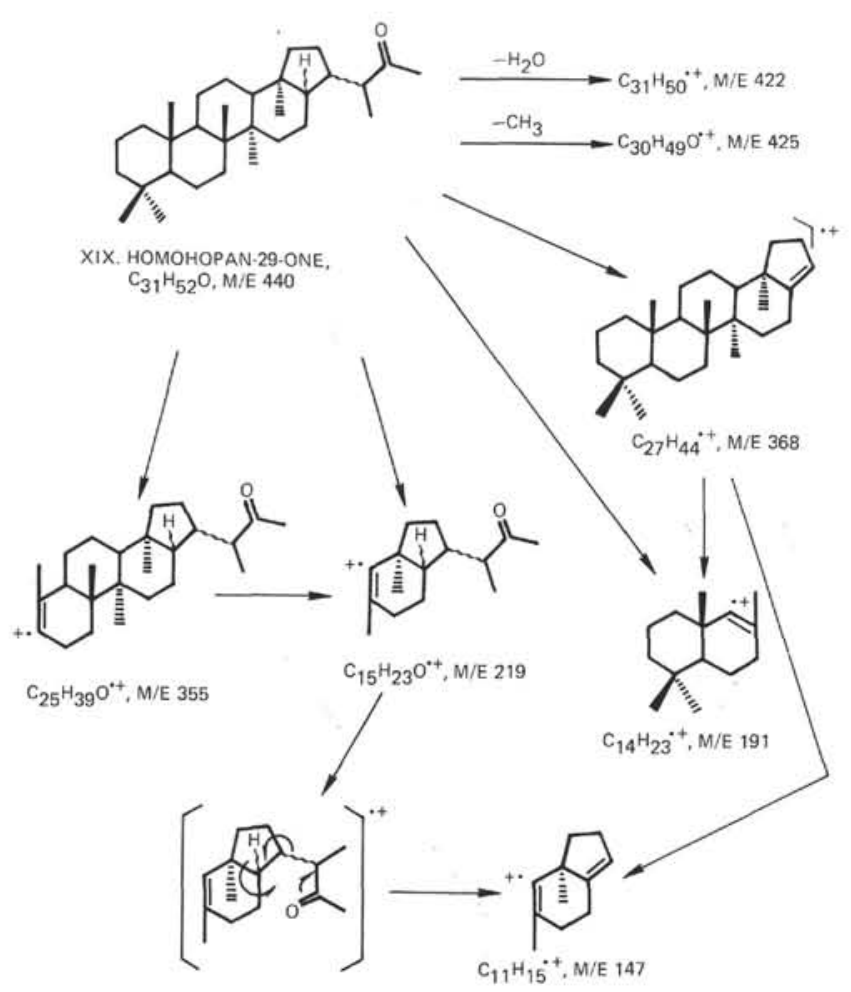

Figure 4. Mass spectrometric fragmentation pattern for the homohopan-29-ones.

financial support from the Energy Research and Development Administration [Grant E(04-3)-34, P.A. 134] is gratefully acknowledged. I thank Dr. Shmuel Brenner and Dr. Ansis Kaneps for their review of the manuscript.

\section{REFERENCES}

Arpino, P., 1973. Les lipides des sédiments lacustres éocènes, Thesis, 1'Université Louis Pasteur de Strasbourg, France.

Dastillung, M. and Albrecht, P., 1976. Molecular test for oil pollution in surface sediments, Mar. Poll. Bull., v. 7, p. 13-15.

Didyk, B.M., Simoneit, B.R.T., Brassell, S.C., and Eglinton, G., 1978. Geochemical indicators of paleoenvironmental conditions of sedimentation, Nature, v. 272, p. 216-222.

Greiner, A.C., Spyckerelle, C., and Albrecht, P., 1976. Aromatic hydrocarbons from geological sources - I. New naturally-occurring phenanthrene and chrysene derivatives, Tetrahedron, v. 32 , p. $257-260$.

Hatcher, P.G., Simoneit, B.R., and Gerchakov, S.M., 1977. The organic geochemistry of a Recent sapropelic environment: Mangrove Lake, Bermuda. In Campos, R., and Goni, J. (Eds.), Advances in organic geochemistry 1975: Madrid, ENADIMSA, p. 469-484.
Montadert, L., Roberts, D.G., Auffret, G.A., Bock, W.D., Dupeuble, P.A., Hailwood, E.A., Harrison, W., Kagami, H., Lumsden, D.M., Müller, C., Schnitker, D., Thompson, R.W., Thompson, T.C., and Timofeev, P.P., 1976. From Brest to Aberdeen Glomar Challenger sails on Leg 48, Geotimes, v. 21 (12), p. 19-23.

Rohmer, M., 1975. Triterpenoides de procaryotes, Ph.D. thesis, l'Université Louis Pasteur de Strasbourg, France.

Schlanger, S.O. and Jenkyns, H.C., 1976. Cretaceous oceanic anoxic events: Causes and consequences, Geol. en Mijnbouw, v. 55, p. $179-184$.

Simoneit, B.R.T., 1973. Appendix I. Identification of isoprenoidal ketones in Deep Sea Drilling Project core samples and their geochemical significance. In Burns, R.E., Andrews, J.E., et al., Initial Reports of the Deep Sea Drilling Project, v. 21: Washington (U.S. Government Printing Office), p. 909-923.

1975. Sources of organic matter in oceanic sediments, Ph.D. Thesis, University of Bristol, England.

, 1977a. The Black Sea, a sink for terrigenous lipids, Deep-Sea Res., v. 24, p. 813-830.

, 1977b. Diterpenoid compounds and other lipids in deep-sea sediments and their geochemical significance, Geochim. Cosmochim. Acta, v. 41, p. 463-476.

, 1977c. Leg 41 sediment lipids - Search for eolian organic matter in Recent samples and examination of a black shale. In Lancelot, Y., Seibold, E., et al., Initial Reports of the Deep Sea Drilling Project, Supplement to Volumes 38, 39, 40, and 41: Washington (U.S. Government Printing Office), p. 855-858.

, 1978. Organic geochemistry of terrigenous muds and various shales from the Black Sea, DSDP Leg 42B. In Ross, D., Neprochnov, Y., et al., Initial Reports of the Deep Sea Drilling Project, v. 42, Part 2: Washington (U.S. Government Printing Office), p. 749-753.

, 1979. Organic geochemistry of the shales from the northwestern Proto-Atlantic, DSDP Leg 43. In Tucholke, B., Vogt, P., et al., Initial Reports of the Deep Sea Drilling Project, v. 43: Washington (U.S. Government Printing Office), p.643-650.

in press a. Organic geochemistry of the shales and sapropels of the Cretaceous Atlantic. In 8th Internatl. Meeting of Organic Geochemistry, Proc., U.S.S.R. Acad. Sci. Moscow.

, in press b. Terrigenous and marine organic markers and their input to marine sediments. In Baker, E.W. (Ed.), Symp. Org. Geochem. of DSDP Sediments Proc.: Princeton (Science Press).

Simoneit, B.R.T. and Kaplan, I.R., in press. Triterpenoids as molecular markers of paleoseepage in Recent sediments of the Southern California Bight, Mar. Environm. Res.

Spyckerelle, C., 1975. Constituants aromatiques de sédiments, $\mathrm{Ph} . \mathrm{D}$. Thesis, l'Université Louis Pasteur de Strasbourg, France. 
APPENDIX

Chemical Structures Cited in Text

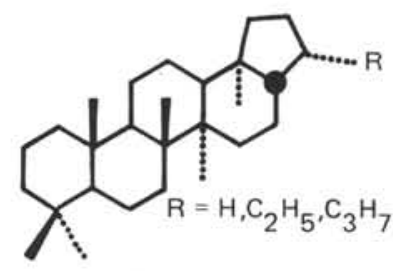

I. $17 \beta(H), 21 \beta(H)$-hopanes

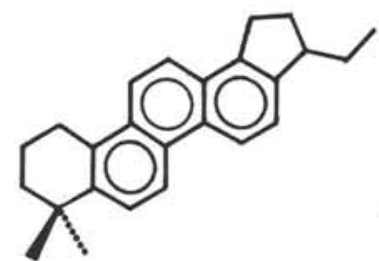

IV. ethylcyclopentenodimethyltetrahydrochrysene

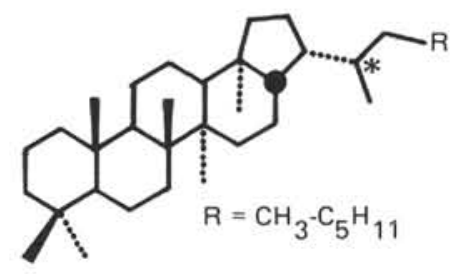

II. extended $17 \beta(H), 21 \beta(H)$-hopanes

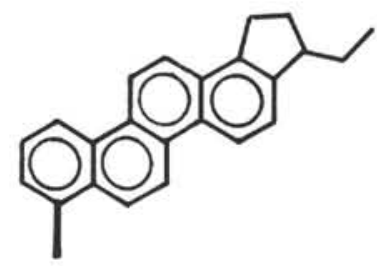

V. ethylcyclopentenomethylchrysene

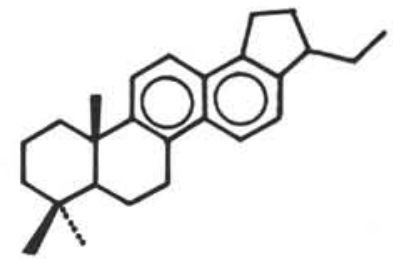

III. ethylcyclopentenotrimethyloctahydrochrysene

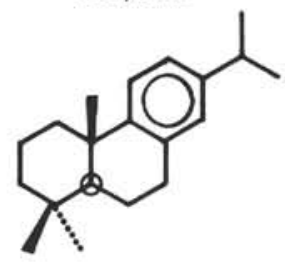

VI. dehydroabietane

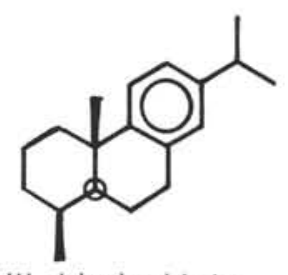

VII. dehydroabietin

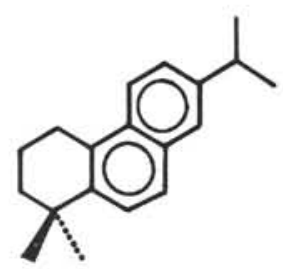

VIII. simonellite

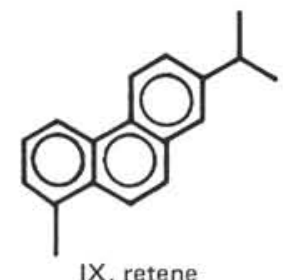

IX. retene

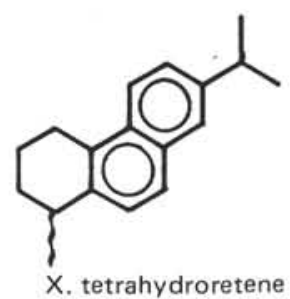

XII. tetrahydrocadalene

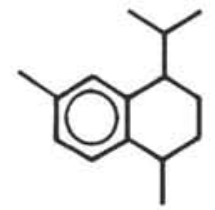

XI. 17-nordehydroabietan

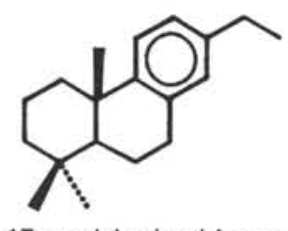

${ }_{R=\mathrm{CO}_{2} \mathrm{H}, \mathrm{CH}_{2} \mathrm{CO}_{2} \mathrm{H}, \mathrm{CH}_{2} \mathrm{CH}_{2} \mathrm{CO}_{2} \mathrm{H}}$

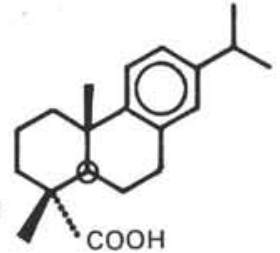

$X V$. dehydroabietic acid

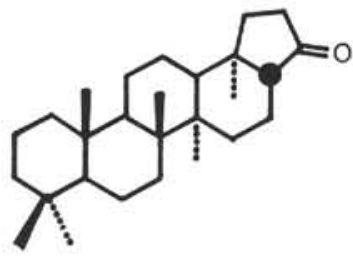

XVI. $17 \beta(H)$-trisnorhopan-21-one

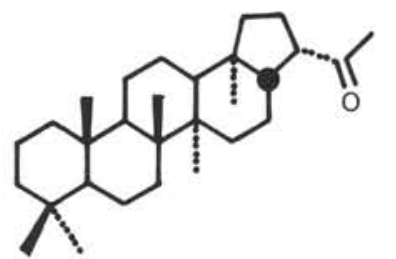

XVII. $17 \beta(H), 21 \beta(H)$-norhopan-22-one

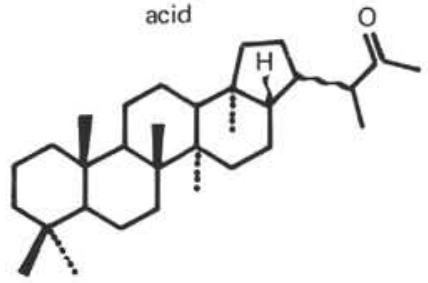

XVIII. homohopan-29-one

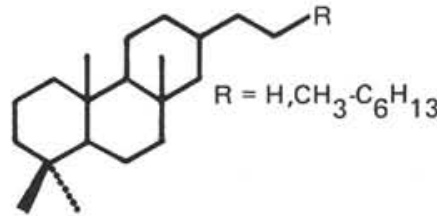

XIX. diterpanes 